\title{
Psychological and Pedagogical Conditions of Successful Assimilation of Psychology and Conflictology by Law Students
}

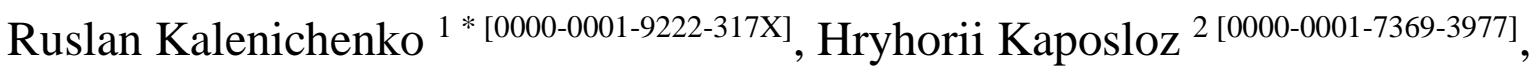 \\ Iirina Petukhova 3 [000-0002-5194-5333] \\ ${ }^{1}$ Kyiv National University of Civil Engineering and Architecture, Ukraine \\ ${ }^{2}$ Kyiv National University of Trade and Economics, Ukraine \\ ${ }^{3}$ University of the State Fiscal Service of Ukraine, Irpin, Ukraine \\ *1971_rak@ukr.net
}

\begin{abstract}
The article, based on an empirical study of the relationship of psychological characteristics of law students with the success of the discipline "Professional Psychology and Conflict Studies", proposes an approach to increase the success of students of non-core specialties in psychology and conflict studies conditions of study of students. Namely: for express diagnostics of the level of development of psychological characteristics of students during the organization of educational process the use of indicators is recommended: productivity of graphic imagination, productivity of verbal imagination, mechanisms of psychological protection; during the organization and conduct of the educational process (classes, trainings) proposed to use a model that ensures the organization of the educational process on the principles of: ensuring the interaction of motivational-target, emotional-protective and content-operational components (components) of the psychological structure of personality; formulation and solution of educational tasks from simple to complex (question, task, situation).
\end{abstract}

Keywords: success, academic discipline, personality, psychological structure, psychological and pedagogical conditions

\section{INTRODUCTION}

Instruction in institutions of higher education is a key stage in the professional training of personality. Success of the training, formation of a positive attitude of the young person to the chosen profession, his readiness to perform its functions depends on the organization of the educational process [1-4]. The academic discipline "Professional Psychology and Conflictology" occupies a special place in the professional development of students of various specialties, including of a legal, as it provides the prerequisites for successful professional socialization of the personality, namely:

Formation of an idea about the nature of the psyche and its manifestations, personality and its structure, communication and interaction of people activities, its structure and its types, conflicts and their types;

Acquisition of practical skills to know oneself and others, to analyze one's professional activities and to build relationships in occupational groups, to identify and resolve interpersonal conflicts.

Production of skills to predict and control one's own psychological state, situation of professional interaction, to positively perceive conflict and pragmatically use it.

\section{RESEARCH ANALYSIS}

Babina T. G. \& Ershova O. P. in their work [5] they view success as a multidimensional phenomenon with different vectors of individual assessment of achieving a result: self-targeting (I'm successful because I realized my plan) or on other entities (I'm a success because the best in a certain field). Bakshtansky V. L. \& Zhdanov O. I. [6] develop rules to effectively implement the personal plan and achieve success in different spheres of life, Kovalev S. V. [7] explores in his works the practical application of neurolinguistic programming techniques for ensure personal growth.

Among the studies of success, a special place is occupied by works devoted to the analysis of indicators 
of the effectiveness of teaching pupils and students.

Fallah, M. H. \& Ubell, R. [8] comparing midterm exams found a little difference in the success of Stevens Institute of Technology students who studied online and in traditional ways. In research of Filenko B. M., Roiko N. V. \& Starchenko I. I. [9] have found the negative impact of forced (due to pandemic conditions) distance learning using Zoom and Google Classroom platforms on the performance of medical students compared to traditional education.

The different findings of the above studies may be explained by the influence of other factors on learning outcomes, such as:

Features of interaction (constructive feedback, guidance and support) of teacher and student. Swan K., Shea P., Fredericksen E., Pickett A, Pelz W. \& Maher G. [10] has determined significant correlations between student-to-student relations to learning and feedback (interaction) with teachers, between student-tostudent attitudes to learning and communication (interaction) with peers, and between students' conscious activity in courses (interactions with structure) and students' attitudes to learning. Garrison, D. R., Anderson, T. \& Archer, W. [11] report such findings;

The design in which educational material is presented. Research on online courses has shown that their structure is based on the data of Romiszowski, A. J. \& Cheng, E. data [12], transparency according to Eastmond, D. V. data [13] and communication potential according to Irani T. data [14] strongly influence the effectiveness of student learning.

In any educational institution, the teacher acts as an expert who plans interaction and stimulation of interest of the pupils in order to motivate them to participate in the educational process. In the studies presented by Grechanovskaya O. V. [15] \& Voshkolup G. Y. [16], a structural-functional model of the pedagogical system for the formation of conflictological culture and the technology of competence of future specialists in technical specialties, economists in the process of studying humanities was developed.

On the basis of our analysis, we can assume that there are psychological and pedagogical success factors in the formation of prerequisites for successful professional socialization of the personality in institutions of higher education.

Thus, the relevance of the research of psychological and pedagogical factors of success in the study of academic discipline "Professional Psychology and Conflictology" is associated the success of students and students of non-core (non-psychological and pedagogical) specialties in mastering knowledge of psychology and conflictology.

\section{THE PURPOSE OF THE PAPER}

In the process of researching the peculiarities of the interaction of the components of the psychological structure of the personality of law-students field and their influence on the success of the study of the academic discipline "Professional Psychology and Conflictology" define the psychological and pedagogical conditions for increasing success in knowledge of psychology and conflictology by students of non-core specialties are determined.

Purpose of the article: to determine the psychological and pedagogical conditions for improving the success of mastering the knowledge of psychology and conflictology by students of non-core specialties in the process of studying the interaction of components of the psychological structure of the personality of studentlaw during the study of "Professional Psychology and Conflictology".

\section{THE MAIN MATERIAL}

\section{Methods used in the study.}

A set of methods was used to solve the tasks, achieve the goal and test the research hypothesis.

In order to diagnose the development of imagination and thinking used techniques:

to determine the level of imagination, the degree of its flexibility or rigidity during the construction of a graphic image - the method of "Creative Imagination";

to study the features of the creative imagination during operations with words - the method of "Creative Imagination" ("Three words");

to determine the level of development of personality creativity - "Guilford Test";

to determine the level of formation of general creative abilities of the individual used the Methodology of the same name.

To determine the motivation of the individual used the Method of diagnosing the personality to motivate the success of T. Ehlers.

To identify and quantify the structure of the mechanisms of psychological protection of the individual, a questionnaire for diagnosing the typologies of psychological protection of G. Kellerman and R. Plutchik was used.

To determine the success of the study of the discipline used the method of expert (scaled) assessment of learning outcomes.

Methods of mathematical statistics (correlation analysis) in the package of statistical data processing "SPSSStatistics 17.0" were used to calculate the information array. 
The research was conducted by interviewing respondents - second-year law students of the TAX Police Faculty of the National Fiscal Service University of Ukraine, November-December 2020. The sample was formed randomly - a survey of students who were not involved in the performance of functional duties at the time of the study.

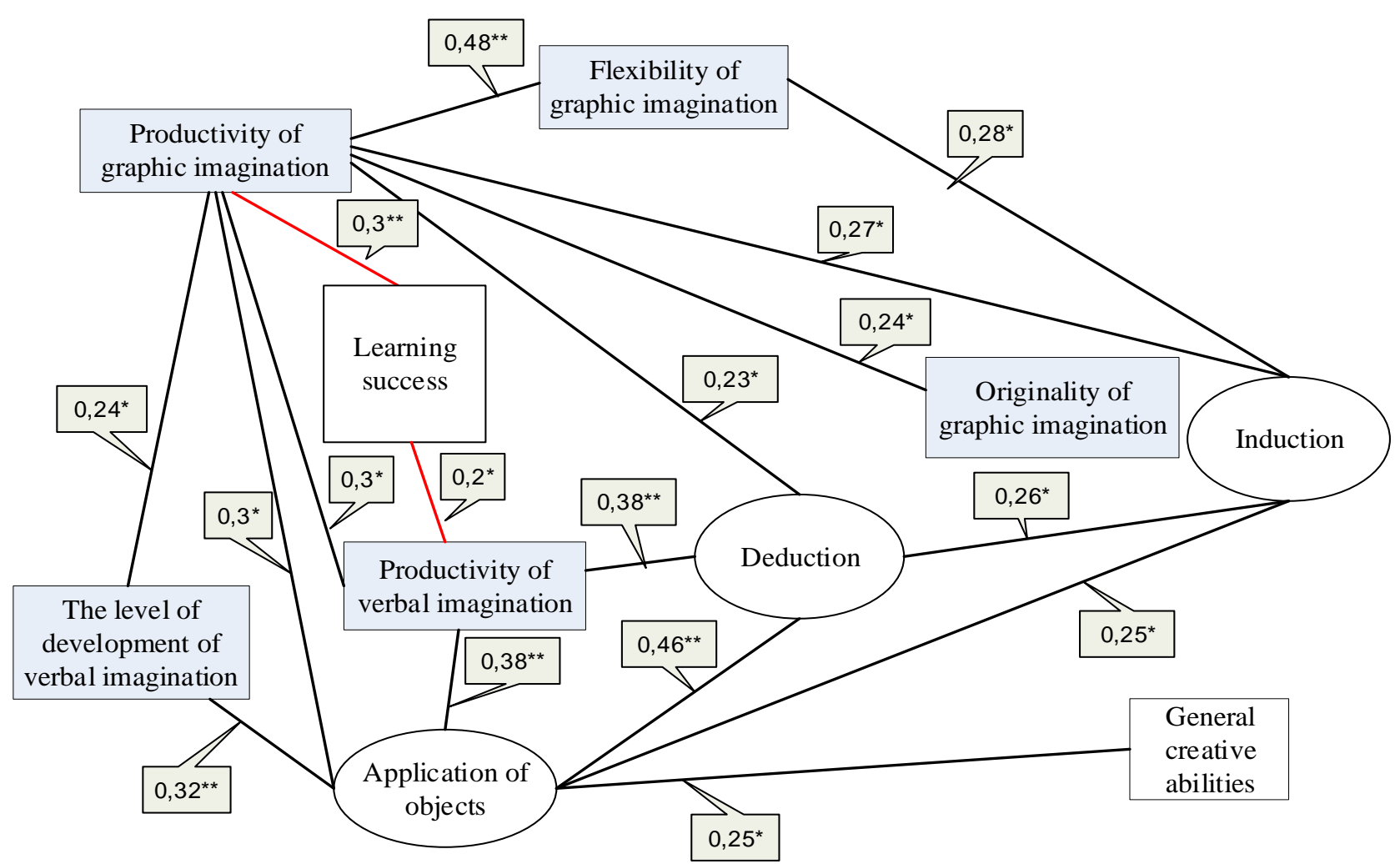

Pigure 1 The structure of the correlation between indicators of imagination, thinking, and learning success

$$
\begin{aligned}
& \text { - indicators of thinking development; } \\
& \text { - indicators of graphic and verbal imagination development; } \\
& \text { - success of educational activities; } \\
& \text { - the correlation is significant at the level of } 0.05 \text { (bilateral); } \\
& * * \text { - the correlation is significant at the level of } 0.01 \text { (bilateral). }
\end{aligned}
$$

A detailed analysis of the connections presented in the diagram allows us to make the following assumptions:

a) the success of the study of the discipline by law students (academic success) has a linear direct (positive) relationship with the level of productivity of creative graphic and verbal imagination;

b) the functioning of the processes of imagination and thinking takes place in a dialectical relationship at the levels of graphic images and verbal signs, with the use of induction, deduction and combination (production of options for the use of the subject);

c) the effectiveness of the interaction (synthesis) of imagination and thinking, which is manifested in the ability to produce new variants of graphic images and connections of verbal signs, determines the success of student learning.

Thus, it is established that the developed imagination as the ability to operate with graphic and verbal images is extremely important for the development of the discipline by a law student: its high level ensures high academic performance, enriches the cognitive sphere of personality, filling with positive emotions, constructive thoughts and volitional actions. professional thinking and the ability to model the situation in the imagination, to anticipate all possible ways to solve operational and service tasks and choose the best among them.

In addition, we found links between achievement motivation and the mechanisms of psychological protection of the individual, as well as the latter with the 
success of learning. Calculated (in accordance with the requirements of statistical methods of data processing) correlation coefficients allowed to present linear relationships between indicators (Figure 2)

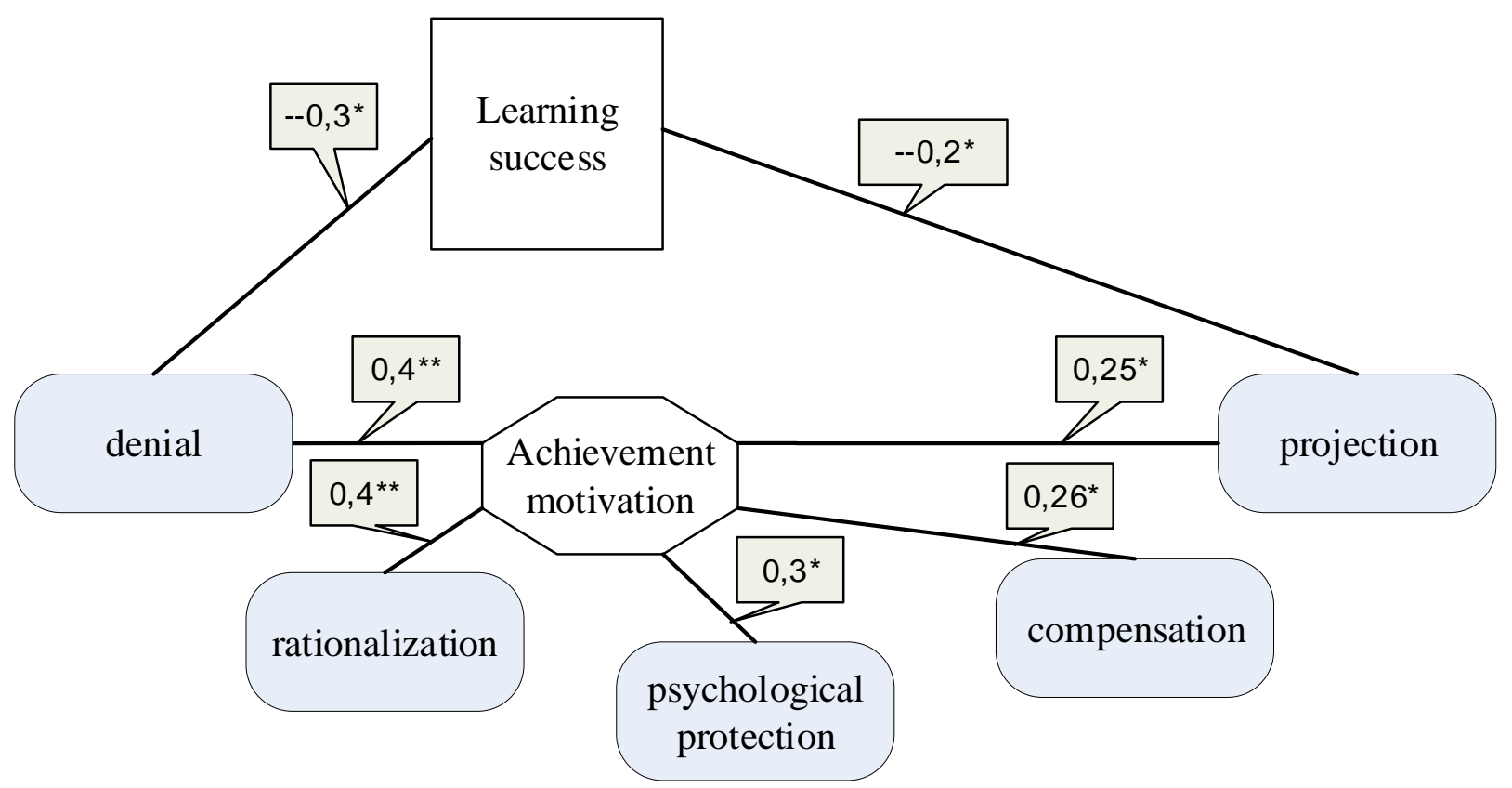

Figure 2 The structure of correlations between indicators of achievement motivation, mechanisms of psychological protection of the individual and successful learning

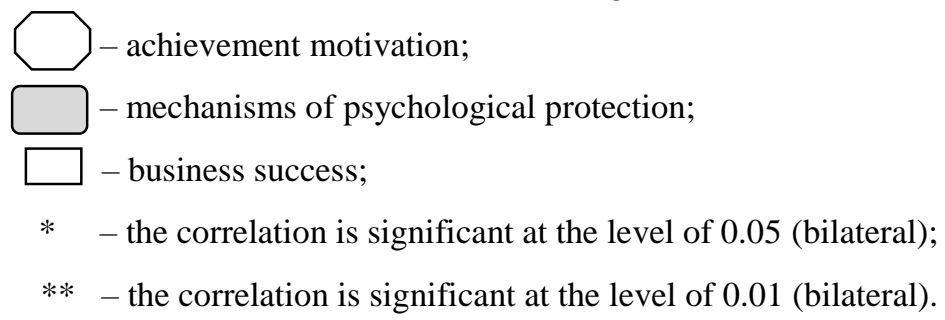

A detailed analysis of the connections presented in the diagram allows us to make the following assumptions:

a) direct, weak $(r=0.25-0.4)$, significant $(p<0.05)$ and highly significant $(\mathrm{p}<0.01)$ connections between the values of achievement motivation and the values of psychological defense mechanisms (denial, rationalization, compensation, projection, general tension of mechanisms of psychological protection) indicate that people with the motive of success have more pronounced mechanisms of psychological protection of denial, rationalization, compensation, projection and general tension of mechanisms of psychological protection;

b) inverse, weak $(r=-0.3)$, significant $(p<0.05)$ relationship between performance indicators of problem solving and learning (marked in the diagram) and the mechanism of psychological protection "denial", inverse, weak $(r=-0.2)$, a significant $(p<0.05)$ relationship between performance indicators of problem solving and learning (marked in the diagram) and the mechanism of psychological protection "projection" indicate that people with a high level of motivation success and the manifestation of psychological mechanisms of "denial" and "projection" are less successful in solving problems. And the main reason is not so much the high level of motivation for success, as the refusal to acknowledge the existence of trouble. The mechanism of denial ensures the avoidance of thoughts, feelings, desires or needs of reality that can cause a person pain if recognized. As well as attributing to the external object internal impulses and feelings that are generally unacceptable to the individual. Thanks to the "Projection", these impulses penetrate the consciousness as a changed perception of the external world and there is a misinterpretation of reality;

c) the lack of linear relationships between performance indicators (indicated in the diagram) and the mechanisms of psychological protection "rationalization", "compensation" and the overall intensity of the mechanisms of psychological protection confirms the previous conclusions. It also explains to some extent the weakness of the linear connections we 
have identified, as it suggests the existence of another form of connection.

Thus, it is established that: the motivational orientation of students' activities is related to the level of psychological protection of the individual, as well as its mechanisms: denial, rationalization, compensation and projection; the level of development of the motivationalvalue component affects the effectiveness of learning indirectly, through the mechanisms of psychological protection: "denial" and "projection". The indirect link between motivation and performance by the mechanisms of psychological defense of denial and projection suggests that students with a high level of achievement motivation are less willing to take risks, and hopes for success are usually more modest than students with a medium level of achievement motivation.

The identified patterns allow to form requirements for the psychological and pedagogical conditions of successful study of the discipline "Professional Psychology and Conflict Studies" by Tax Police students.

The main psychological conditions (components of the psychological structure of personality that should be controlled for) the successful study of the discipline are:

formation and maintenance of interest in the content of educational material and the learning process sufficient to motivate students to study the discipline (motivational-target component);

avoidance of subconscious distortion of perception of the real state of affairs (emotional-protective component);

taking into account the level of development of imagination and thinking, the dynamics of their development in students during the organization of the educational process (formation of content, form and definition of time limits for the presentation of educational material) - content-operational component.

Based on the psychological conditions of successful study of the discipline "Professional Psychology and Conflict Studies", the basic pedagogical conditions of learning effectiveness are updated:

educational material for the purposes of forming a system of knowledge;

significance for students (compliance with the motivational orientation) of the educational material (information) taught;

formation of educational material with a focus on the area of immediate development (according to L. Vygotsky);

ensuring consistency and accessibility (from simple to complex) of the educational material and educational situations offered to students (problem questions, problem tasks, problem situations); realization of dialogic friendly communication of the teacher with students, when all opinions, hypotheses expressed by students are treated with attention and encouragement

Based on the above in the process of organizing student learning is essential to activate, develop and use the psychological characteristics of students in order to achieve high performance, and the learning activity should cause their own cognitive activity and activity of students.

The work allowed to develop a model of organization of the educational process of law students, taking into account the peculiarities of the interaction of some components of the psychological structure of personality (Figure 3).

The proposed model of organizing the interaction of the components of the psychological structure of the personality of law students during the study of the discipline "Professional Psychology and Conflict Studies" has four stages:

The first stage is the actualization of basic knowledge and methods of action. At this stage, measures are taken to update the existing and form the necessary motivation of students to master the profession of taxpayer, forming students' ideas about emotions and mechanisms of psychological protection and their role in professional activities, thus creating conditions for, adequate perception of the object, the subject of the discipline and awareness of the purpose and objectives and features of its study;

Stage II - learning new knowledge and methods of action. The training material is presented in the form of a case of basic questions (elements of a psychological problem), a combination and answer to which provides solutions to most psychological problems that accompany professional activities, in particular, and determine their own motivation and mechanisms of psychological protection. Thus, the functioning of the content-operational component is aimed at mastering the methods and technologies of applied psychological research and their application to determine and understand students' own characteristics of motivation (motivational-target component) and mechanisms of psychological protection (emotional-protective component);

Stage III - development of skills and abilities. At this stage, learning is based on a case of psychological problems identified by the teacher on the basis of analysis of professional activities and experience of successful solution of psychological problems that accompany it. The condition of each problem is constructed in such a way that the situation is simple enough for independent analysis and finding the unknown, and at the same time complex enough that the student could not solve it based on existing knowledge (rational ratio of known and 
unknown). The result of the decision (educational product) is unknown to the student, and is controlled by the teacher.

Thus, the tasks are an additional (to the actualized in the first stage) incentive that allows you to develop and correct the motivation of cadets (motivational-target component) as a basis for mastering methods and technologies for solving psychological problems (content-operational component). Mastering the technology of solving psychological problems begins with teaching cadets technologies to take into account emotional reactions and mechanisms of psychological protection (emotional-protective component) in solving psychological problems - special attention is paid to working with individuals with high values of "projection" and "denial";

Stage IV - consolidation of skills and abilities. The training material is presented in the form of a case study of problem situations and technologies for their solution. Learning is built in a more complex version, when the result of solving a problem situation (the result of using technology) is unknown not only to the student but also to the teacher (coach) and is formed in practical classes. To do this, each situation is described in such a way that the student could not solve it based on existing knowledge of psychological problems, but clear enough for independent analysis and finding the problem and a combination of psychological problems to solve it (rational ratio of known and unknown).



Figure 3 Model of the organization of interaction of components of psychological structure of the personality of law students during studying of an academic discipline "Professional psychology and conflictology"

This approach requires students to show psychological readiness to act in problematic situations of a social nature. Observation and correction of motivation (motivational-target component) and mechanisms of psychological protection (emotionalprotective component) of students is also the task of the teacher.

\section{CONCLUSIONS}

The article proposes a new approach to solving the current practical problem of "increasing the success of mastering the knowledge of psychology and conflict studies by students of non-core specialties" and the scientific task of determining the optimal psychological and pedagogical conditions for students. The results of the experimental study allow us to draw conclusions.

1. In the process of substantiation of methods and the order of research the indicators on which, during empirical research, the estimation of the following psychological characteristics of students was carried out are defined: 
imagination - productivity of graphic imagination, flexibility of graphic imagination, originality of graphic imagination, productivity of verbal (creative) imagination, level of development of creative (verbal) imagination;

thinking - productivity of thinking during the application of objects, productivity of thinking during deduction, productivity of thinking during induction;

the level of formation of general creative abilities;

motivation - motivation to achieve;

mechanisms of psychological protection displacement, regression, substitution, denial of reality, projection, compensation, reactive formations, rationalization, tension of mechanisms of psychological protection;

learning effectiveness - expert scale (from 0 to 70 ) assessment of the success of acquiring knowledge from the course "Professional Psychology and Conflict Studies".

2. According to the results of the analysis of correlations between the defined indicators it is established that the most informative indicators are:

by the number of correlations with other indicators of imagination and thinking - indicators of productivity of graphic imagination (8), productivity of thinking in determining the use of objects (6). The established connections allow to recommend the use of certain indicators for rapid diagnosis of the level of development of imagination and thinking of students during the organization of the educational process; in the presence of correlations with the assessment of learning success an indicator of the productivity of the graphic imagination $(\mathrm{r}=0.3$ at $\mathrm{p} \leq 0.01)$, an indicator of the productivity of the verbal imagination $(\mathrm{r}=0.2$ at $\mathrm{p} \leq$

\section{REFERENCES}

[1] Kyrpychenko, Olena Pushchyna, Iryna Kichuk, Yaroslav Shevchenko, Nataliia Luchaninova, Olga and Koval, Viktor (2021), "Communicative Competence Development in Teaching Professional Discourse in Educational Establishments ", International Journal of Modern Education and Computer Science (IJMECS), vol. 13, no. 4, pp. 16-27. DOI: $10.5815 /$ ijmecs.2021.04.02

[2] Mohammed Abdullah Al-Hagery, Maryam Abdullah Alzaid, Tahani Soud Alharbi and Moody Abdulrahman Alhanaya (2020), "Data Mining Methods for Detecting the Most Significant Factors Affecting Students' Performance", International Journal of Information Technology and Computer Science (IJITCS), vol. 12, no. 5, pp.1-13. DOI: $10.5815 /$ ijitcs.2020.05.01
$0.05)$, indicators of the mechanisms of psychological protection of "negation" ( $\mathrm{r}=-0.3$ at $\mathrm{p} \leq 0.05)$ and "projection" ( $r=-0.2$ at $p \leq 0.05)$. Thus, the developed imagination as the ability to operate with graphic and verbal images is extremely important for the development of the discipline by a law student: its high level ensures high academic performance, enriches the cognitive sphere of personality, filling with positive emotions, constructive thoughts and volitional actions. And the level of development of the motivational-value component affects the effectiveness of solving problem tasks indirectly, through the mechanisms of psychological protection: "denial" and "projection".

3. Awareness of the identified dependencies and their use in the organization and conduct of the educational process (classes, trainings) will contribute to the more rapid development of the ability of law students to use the knowledge of psychology in practice. The proposed model of this process provides the organization of the educational process on the principles of:

ensuring the interaction of motivational-target, emotional-protective and content-operational components (components) of the psychological structure of personality;

formulation and solution of educational tasks from simple to complex (question, task, situation);

4. The study does not cover all aspects of the problem. In addition, the obtained patterns suggest that the formation and maintenance of personality motivation, development of imagination and thinking, taking into account the peculiarities of the mechanisms of psychological protection will help to actively develop students' ability to solve problems (answer problems, solve problems, act in problematic situations). Testing this hypothesis is the direction of further research.

[3] Mussa S. Abubakaria, Fatchul Arifin and Gilbert G. Hungilo (2020), "Predicting Students' Academic Performance in Educational Data Mining Based on Deep Learning Using TensorFlow", International Journal of Education and Management Engineering (IJEME), vol. 10, no. 6, pp.27-33. DOI: $10.5815 /$ ijeme.2020.06.04

[4] Madhuri T. Sathe and Amol C. Adamuthe (2021), "Comparative Study of Supervised Algorithms for Prediction of Students' Performance", International Journal of Modern Education and Computer Science (IJMECS), vol. 13, no. 1, pp. 121. DOI: $10.5815 / \mathrm{ijmecs} .2021 .01 .01$

[5] Babyna, T.H. and Yershova, O.P. Uspishnist yak bahatovymirnyi fenomen, Mizhnarodna naukovopraktychna konferentsiia "Uspishnist osobystosti: potentsial ta obmezhennia", available at: http://www.psyscience.com.ua/department 
[6] Bakshtanskyi, V.L. and Zhdanov, O.Y. (1999), Pryhlashenye k uspekhu, Rus. kn., Moskva, Rossia.

[7] Kovalëv, S.V. Psykhoterapyia neobkhodymoho samosovershenstvovanyia, available at: https://psyin.ru/articles/psihoterapiya-neobhodimogosamosovershenstvovaniya

[8] Fallah, M. H. and Ubell, R. (2000), "Blind scores in a graduate test", Conventional compared with web-based outcomes, ALN Mgazine, vol. 4 (2), available at: http://www.aln.org/alnweb/magazine /Vol4_issue2/fallah.htm

[9] Fylenko, B.M. Roiko, N.V. and Starchenko, I.I. [ta in.] (2020), "Porivnialnyi analiz uspishnosti studentiv pid chas dystantsiinoho navchannia $\mathrm{i}$ tradytsiinoi formy osvity", Visnyk Ukrainskoi medychnoi stomatolohichnoi akademii "Aktualni problemy suchasnoi medytsyny”, T. 20, vyp. 3 (71), ss. 245-248.

[10] Swan, K. Shea, P. Fredericksen, E. Pickett, A. Pelz, W. and Maher, G. (2000), "Building knowledge building communities: consistency, contact and communication in the virtual classroom", Journal of Educational Computing Research, vol. 23 (4), pp. 389-413.

[11] Garrison, D. R. Anderson, T. and Archer, W. (2001), "Critical thinking, cognitive presence, and computer conferencing in distance education", The American Journal of Distance Education, vol. 15 (1).
[12] Romiszowski, A.J. and Cheng, E. (1992), "Hypertexts contribution to computer-mediated communication: in search of an instructional model", In Giardina, $M$. (Ed.) Interactive Multimedia Learning Environments, Springer, Berlin.

[13] Eastmond, D.V. (1995), Alone but Together: Adult Distance Study through Computer Conferencing, NJ: Hampton Press, Cresskill.

[14] Irani, T. (1998), "Communication potential, information richness and attitude", A study of computer mediated communication in the ALN classroom, ALN Magazine, vol. 2 (1).

[15] Hrechanovska, O.V. (2020), Pedahohichna systema formuvannia konfliktolohichnoi kultury $v$ maibutnikh fakhivtsiv tekhnichnykh spetsialnostei, Dysertatsiia na zdobuttia naukovoho stupenia doktora pedahohichnykh nauk 13.00.04 - teoriia i metodyka profesiinoi osvity, Vinnytsia, available at: https://vspu.edu.ua/content/specialized academic_council/doc/2020/Grechanska_O_W/dis .pdf

[16] Voshkolup, H.Yu. (2017), Formuvannia konfliktolohichnoi kompetentnosti maibutnikh ekonomistiv u protsesi vyvchennia humanitarnykh dystsyplin, Dysertatsiia na zdobuttia naukovoho stupenia kandydata pedahohichnykh nauk 13.00.04 - teoriia ta metodyka profesiinoi osvity, Dnipro, available at: https://duan.edu.ua/images/head/ Science/UA/Academic_Council/K_08_120_02/20 561.pdf 